\title{
Investigating the Causes of Learners' Speaking Anxiety in Foreign Language Classroom: The Case of Grade Nine Students in Mizan Secondary and Preparatory School in Bench Maji Zone in Snnpr
}

\author{
Amanuel Kidane Albore \\ English Language and Literature, Wolaita Sodo University, Wolaita Sodo, Ethiopia
}

\section{Email address:}

amankidistlove@gmail.com

\section{To cite this article:}

Amanuel Kidane Albore. Investigating the Causes of Learners' Speaking Anxiety in Foreign Language Classroom: The Case of Grade Nine Students in Mizan Secondary and Preparatory School in Bench Maji Zone in Snnpr. Arabic Language, Literature \& Culture.

Vol. 4, No. 1, 2019, pp. 1-15. doi: 10.11648/j.allc.20190401.11

Received: February 18, 2019; Accepted: March 30, 2019; Published: May 11, 2019

\begin{abstract}
This study investigated causes of learners speaking anxiety in foreign language classroom with the reference to grade nine in Mizan Secondary and Preparatory School in Bench Maji zone in SNNPR. Mixed research method was used to conduct the study. Subjects of the study were one hundred fifty four systematically selected students and eleven purposively selected teachers (teaching English in grades nine and ten). Three data collection tools were used, namely, questionnaire, written reflection, and interview (semi structured interview). Questionnaires are the personalized form of Foreign Language Classroom Anxiety Scale (FLCAS) which was developed by Horwitz et al [13] in order to investigate the cause of speaking anxiety. And also, Interview (semi structured interview) and written reflection were conducted with purposively selected teachers and students to identify the cause of speaking anxiety. Accordingly, the findings showed that most students do experience anxiety which had a debilitating effect on foreign language speaking. Consequently, several sources of anxiety provoking factors were discussed in this study to deepen our understanding of anxiety in speaking foreign language. For example, lack of self-confidence, incomprehensible input and lack of prior preparation were found the great contributors of communication apprehension. Further analysis of data revealed that fear of making mistakes, feedback provision, students self perception, failure of oral tests, limited knowledge of vocabulary and lack of adequate practice in the target language were found some anxiety provoking factors discussed in this study. Similarly, the impact of speaking anxiety in terms of classroom participation, language performance and achievements and social problems were identified. On the basis of the findings, the research was finalized with some recommendations and suggestions to investigate the causes of speaking anxiety in foreign language speaking classroom.
\end{abstract}

Keywords: Anxiety, Foreign Language Classroom Anxiety Scale, Cause, Bench Maji

\section{Introduction}

Anxiety is a kind of emotion which can be considered as complicated state of mind. Anyone can be affected by anxiety. The feeling of anxiety is associated with fear. When we are afraid of something we know the reasons but for the anxiety, the causes are not specific, sometime it is vague. Anxiety manipulates our thought process and also regulates our feeling. Anxiety has been considered as a very negative factor in learning a foreign language, especially in learning to speak the language. In Horwitz et al. [13] it is indicated that anxiety is a major obstacle in learning to speak foreign language. It has been observed that students in English classroom experience anxiety. Students with anxiety will have difficulty concentrating and processing input in class and consequently the output of the language is negatively affected. Several studies have revealed that anxiety impedes foreign language learning and achievement.

Some local researchers also tried to investigate the 
relationship between anxiety and second language learning; for example, Sutarsyah's [23] study, which found negative effects of anxiety on speaking performance among Junior High School students, may give a glimpse of idea on the possible relationship between anxiety and speaking performance. However, the small number of participants in that study may indicate that studies involving a bigger number of participants are needed to further confirm the finding on the anxiety-performance relation. Besides, different contexts and different level of education may be at play in influencing learners' anxiety. Hence, a study on anxiety and performance among students of a different context and level of education may give a deeper understanding of this area. Likewise, Han et al. [12] investigated the impact of communication classes taught by native English speaking teachers and non-native English speaking teachers on EFL students' and teachers' attitudes toward foreign language speaking anxiety. Their findings indicated no significant difference between the students' attitudes toward anxiety and their gender. Similarly, Gerencheal [11] mainly investigated differences of foreign language anxiety between female and male language learners. The foreign language classroom anxiety scale developed by "Horwitz, Horwitz, and Cope [14]" was distributed among 28 female and 50 male English major students at Mizan-Tepi University to measure the level of language learners' anxiety. Results showed that Iranian female EFL learners had a higher score in all anxiety categories than male learners. The main objective of the study was to know factors which cause students to be in a state of anxiety when they take writing tests.

As it is indicated above, most of these studies have been conducted on the relationship between anxiety and achievement with respect to general language learning and delimited to Universities and Colleges; however, the current study is confined to investigate causes for foreign language speaking anxiety in English Language classroom with reference to grade nine in Mizan Secondary and Preparatory School. This indicates that the existing research study may not reflect the real situations of high school because the environment, nature of students and teachers and their linguistic competence may be different from that of university or colleges.

In addition, since foreign language anxiety not only have an effect on students' attitude and language learning but also is considered to have more debilitating effects than facilitating effects, a detailed investigation of the cause of speaking anxiety to our context is necessary and significant. We live in a world where good command of English language is crucial; therefore, in equipping learners with communicative competence, investigating source of speaking anxiety will have a paramount advantage. While most local studies of foreign language anxiety focused on the difficulties caused by anxiety with respect to general language learning, this study attempts to investigate causes of anxiety in foreign language speaking specifically. Furthermore, most of the existing studies related to the current study were done either quantitatively or qualitatively. However, in the current study mixed research approach was used.

\section{Statement of the Problem}

Anxiety, simply speaking, is a kind of troubled feeling in the mind. It is a subjective feeling of tension, apprehension, nervousness, and worry associated with an arousal of the automatic nervous system "Horwitz, [13]". These feelings are considered to exert a potential negative and determinant effect on communication in the target language. Considering this, the use of modern communicative language teaching approaches in the language classroom and the widespread use of English language have increased the demand to learn good communication skills but existence of such feelings in learners may hamper the desired goal of language learning. Speaking English as second language in front of peers is identified as the greatest source of anxiety "Price [22]". It is very likely that learners experience anxiety and reluctance when they are required to perform in a language class. As Horwitz et al. [13] stated that any performance in the second language is likely to challenge an individual's self-concept as a competent communicator and lead to reticence, selfconsciousness, fear, or even panic.

In the intervening time, throughout his teaching experience the researcher has observed that in addressing the aim of language teaching which is equipping learners with good command of English language, speaking anxiety is a serious problem. The researcher also came across that when learners are asked to speak about a given topic they may experience fear. Consequently, when learners experience anxiety, they may skip classes, never volunteer, neglect to turn in homework, avoid speaking in class, or sit in the back of the classroom to minimize the humiliation or embarrassment of being called upon to speak "Horwitz et al., [13]". Learners who fear participation resort, most of the time, to silence as an avoidance strategy. They may sit passively in the classroom. In an oral classroom, for instance, the amount of language production can be influenced by the ways learners perceive themselves, their willingness to communicate and take risks, and by the classroom atmosphere itself which may highly influences communicative language teaching. Surprisingly, teachers may refrain from teaching speaking activities which in turn become an obstacle for current language teaching methodology. Finally, it seems that their language competency will become very weak.

It was also observed that students with anxiety will have difficulty concentrating and processing input in class and consequently the output of the language is negatively affected. They tend to withdraw from voluntary participation and are unwilling to take risks. They are apprehensive, worried and even fearful in the classroom "MacIntyre and Gardner [16]". Such conditions interfere with learning and anxious students are thus deprived of many opportunities to practice the target language. Anxiety is, therefore, considered as a major obstacle in developing language skills and 
particularly speaking skills.

For that reason, what reinforced my curiosity to study on the proposed topic is that the erroneous believes between the aim of current method of language teaching and learning in which learners' participation is highly required and the existing reality in EFL classroom during practicing to speak in the target language. As a result, the researcher thought that investigating causes for speaking anxiety for EFL learners in speaking activities has paramount advantages in improving their communicative competence and classroom participation. It is in their interactions with each other that teachers and students work together to create the intellectual and practical activities that shape both the form and the content of the target language as well as the processes and outcomes of individual development.

\section{Objective of the Study}

The major objective of this study was to explore the factors that cause learners' speaking anxiety in foreign language classroom: the case of grade nine students in Mizan Secondary and Preparatory School, Bench Maji zone in SNNPR.

\section{Research Design and Methodology}

\subsection{Research Design}

The main objective of this study was to explore the factors that cause learners' speaking anxiety in foreign language classroom. To achieve this objective, descriptive research design was employed. The researcher used qualitative and quantitative methods to answer the research questions. This research design was required because social phenomena are so complex and different kinds of methods are needed to best understand these complexities. It helped researcher to freely use different research methods so as to get comprehensive information in studying the proposed problem than either quantitative or qualitative method alone" Onwuegbazie and Leech [21]'.

\subsection{Research of the Setting}

This study was conducted in Mizan Secondary and preparatory school, Bench Maji zone in southern Ethiopia. Bench Maji zone is one of Zones in Southern Nations and Nationalities of Ethiopia commonly known by its oral tradition and population density. The zone has nine Woredas and one City Administration. The major economic activities of Bench Maji are mixed agriculture and trade. Mizan Secondary and preparatory school is found in Mizan town $610 \mathrm{kms}$ far away from Addis Ababa in the Southern direction through Jimma.

\subsection{Population, Sample and Sampling Techniques}

\subsubsection{Subjects of the Study}

This study was to investigate factors that cause speaking anxiety in EFL classroom. Thus, the subjects of the study were selected from grade 9 students of the year 2008. E. C. and their English language teachers of Mizan Secondary and Preparatory School. This is because it was believed that they can provide necessary data for the study. In this school, there are eleven English language teachers who teach grade nine and ten students. All of them were selected as participants of the study. Besides, grade nine students were selected as the participants of this study. This is done because the issue related to speaking anxiety is primarily the concern of learners themselves and their teachers.

\subsubsection{Sample Size and Sampling Techniques}

Secondary and preparatory school was chosen purposively as a study site because the researcher was teaching in the proposed school and he thought that it will enable him to stay in the area to make reliable inquiry. For the time being, there hasn't been any significant research conducted concerning the current study in the proposed school. The school proposed for this study includes secondary and preparatory school. For the purpose of this study secondary school (grade 9) was taken as a sample. Purposive and systematic sampling was employed to select sample respondents. This is because of the nature of mixed method approach. The researcher used FLCAS scale designed by "Horwitz [13]". This scale was selected using systematic sampling that has consisted of 33 items but for the present study there were selected 19 items. The items were $1,2,4,5,6,7,8,9,10,12,15,18,19,21,22$, $23,29,30$, and 33 . Of these seven items linked to communicative apprehension; $(1,4,9,18,22,29$, and 33) three items for fear of negative evaluation; $(2,15,19)$, two items associated with competitiveness; $(7,23)$, three were off for oral test anxiety; $(8,10$ and 21), and four items associated with others causes of speaking anxiety $(5,6,12,30)$. This was done by arranging all grade nine students alphabetically and taking every $15^{\text {th }}$ item in the population after a random starts with an item from 1 to 15 . Conversely, a respondent for interview (semi structured interview) and written reflection were selected purposively. This was done to make the activities manageable.

\subsection{Data Collecting Instruments}

Normally, the choice of data collection methods is determined by the needs of a given research project and in particular by the research questions confronted. Similarly, to collect the required data for this study, three types of instruments: questionnaire, interview (semi structured interview) and written reflection were used. The purpose of using multiple data collection methods is to triangulate the data and to increase the credibility of the study.

\subsection{Data Collection Procedures}

After preparing the instruments, the researcher got the consent of the participants from the selected school, and data for the study was collected using questionnaire adapted from FLCAS, interview (semi structured interview) and written reflection. Before the distribution of the questionnaire, each participant (students) was given code on the mark compiling 
sheet and the subjects were advised to complete the questionnaire genuinely. Then the questionnaire was administered to one hundred fifty four students who were selected using systematic sampling. Written reflection was also distributed to fifteen purposively selected students who were the subjects of the questionnaire. There were eleven English language teachers teaching in grades 9 and 10. Three of them were selected purposively for interview (semi structured interview) and the rest of the teachers were used for written reflection.

\subsection{Data Analysis Procedures}

The data gathered through questionnaire, interview (semi structured interview) and written reflection were analyzed differently using both qualitative and quantitative methods of data analysis in an integrated manner. For example, the entire data collected through questionnaire was analyzed by using quantitative method of data analysis using frequency and percentage those by the interview and written reflection were analyzed by using narration; in a qualitative approach. Then, the interpretation and its discussion were presented in a systematic approach of describing, analyzing and generating conclusion.

\section{Results and Discussions}

\section{Causes of Speaking Anxiety}

The research question of the study is concerned with causes of learners speaking anxiety which has a significant role in language learning. In order to identify causes of learners' speaking anxiety while learning to speak English, questionnaire which is the modification of Foreign Language Classroom Anxiety Scale (FLCAS) which was formulated by "Horwitz et al [13]" and questions for written reflection were administered for students and teachers and interview (semi structured interview) was carried out with English language teachers. Depending on the responses of respondents, common causes of learners' speaking anxiety which they were experiencing during speaking activities were identified and categorized as follows.

\section{(1). Communication Apprehension}

This part details the result obtained from the first category of the FLCAS labeled as communication apprehension which is defined as an individual level of fear or anxiety associated with either real or anticipated communication with another person or persons. In addition, this section also presents the results of the findings obtained from respondents (students) through questionnaire and the result obtained from interview (semi structured interview) made with teachers. This theme deals with problems related to self-confidence, lack of readiness and problems at input stages of learning.

i. Self-Confidence

This theme presents the result concerning the beliefs or feelings of the respondents regarding their ability of speaking the target language. In FLCAL, questions (1) "I never feel quite sure of myself when I am speaking in my oral classroom", and (18) "I feel confident when I speak in English class" are indicators of learners' self-confidence while learning to speak English.

Table 1. Anxiety Scales Related to Low Self Confidence.

\begin{tabular}{lllll}
\hline Items & Statements & Scales & № & \% \\
\hline \multirow{4}{*}{1} & & SA & 50 & $32 \%$ \\
& I never feel quite sure of & A & 70 & $45 \%$ \\
& myself when I am speaking & UN & 0 & 0 \\
& in my oral classroom. & D & 22 & $14 \%$ \\
& & SD & 12 & $9 \%$ \\
\multirow{3}{*}{18} & I feel confident when I & SA & 18 & $12 \%$ \\
& speak in speaking & UN & 38 & $25 \%$ \\
& classroom. & D & 56 & 0 \\
& & SD & 42 & $27 \%$ \\
\hline
\end{tabular}

5= Strongly Agree (SA) 4= Agree (A) 3= Undecided (UN) 2= Disagree (D)

$1=$ Strongly Disagree $(\mathrm{SD}) \mathrm{f}=$ Frequency $\%=$ Percentage

As can be seen from Table 1, the scores of the two questions revealed that students seem that they lose selfconfidence in learning to speak. For example, if we consider the subjects' score in the question (1), more than half of the participants, $120(77 \%)$ agreed or strongly agreed with it. It is evident from the scores that most students lose selfconfidence to use the target language. It seems that most students suffer from communication apprehension. Consequently, lose of confidence to influence students' active participation in speaking activities or avoidance of communicative situations. Anxiety for these students was most often associated with perceiving of being less capable of the language.

Likewise, the question "I feel confident when I speak in my English class", is intended to depict learners' selfconfidence in speaking foreign language. The results of the data indicated that more than half of the participants $98(64 \%)$ strongly disagreed or disagreed with the idea. The scores depicted that most of the students do not feel confident to speak in English. They feel insecure while to speak the target language. This may result from limited knowledge of vocabulary, personal perception, and limited knowledge of the subject matter. As a result, they suffer from anxiety. This means that they were fearful to speak English in front of the class because they may be less familiarized to use English in the classroom. As Daly, [6] hypothesized, the less familiar the situation, the greater the situational apprehension. When topics are unfamiliar, students may feel anxiety and low selfconfidence.

According to the scores of students, it can be deduced that because of their low self-confidence students do experience speaking anxiety which in turn affects their classroom participation. This may result from their avoidance of challenge, feeling of inadequacy, insistence up on perfection and criticism which play a great role in lessening students' self-confidence. Students who lack confidence in themselves both in ability level and ability to communicate suffer from communication apprehension "Horwitz et al [13]". As a result, they fear to speak English in front of the classroom. 
In the light of the students' responses, it can be inferred that lack of sufficient knowledge of vocabulary, fear of misunderstanding, fear to ask help, unfamiliar topics and comprehensive problems (knowledge of the target language) have a significant role in students' self-confidence. It seems that students may not get clear instruction about the topic they deal with and their own personal problems of the subject matter which affects their self-confidence to use the target language. Low self perception may lead to low self confidence. Consistent with Horwitz et al's [13], theory, adults' perceptions of the "true self" are challenged when the "limited self" is presented at any given moment in the foreign language.

Teacher respondents also strengthen this idea indicating that the unavailability of teachers' guide to address the objectives of the lesson can contribute self-consciousness to EFL learners. Activities are available on student's text book without clear instructions. For example, one of the teachers said:

...it is very difficult to give clear instruction for students where there is no teachers guide because some speaking activities were put in the form of picture and topics. If students are not given clear and precise instruction about a certain topic they may confident enough to talk about the topic they don't know (Teacher 5).

The data here suggests that when learners are unfamiliar with the topic to be discussed on, they are likely to experience anxiety and become reluctant to intervene in class discussion. For instance, because they don't know the topic, teachers said that students don't feel self confident in speaking about that topic.

From the data from respondents (teachers and students), we can deduce that when students lack confidence in themselves to communicate, they suffer from communication apprehension which results in fear to participate in class discussions. For MacIntyre and Gardner [16], low self confidence causes reticence or withdrawal from classroom interaction. Daly [6] added that in typical classroom students might avoid talking because they are unprepared, unwilling to disclose, alienated from the class, lacking confidence in their competence or because they fear communication.

In general, the results of the findings indicated that low self-confidence which is assumed to be the cause of communication apprehension results from lack of vocabulary, fear of being misunderstood, dependence on others and unclear instruction and unrelated topics to discuss on.

ii. Lack of Readiness

This category was developed to report speaking anxiety provoked related to lack of prior preparation for speaking classroom in particular and English classroom in general. In FLCAS questions (9) 'I start to [fear] panic when I have to speak without preparation in my speaking classroom', (22) 'I don't feel pressure to prepare very well for English classes' and (33) 'I get nervous when my English teacher asks questions which I haven't prepared in advance" are indicators of prior preparation for the regular speaking classroom before it starts. The scores of responses are illustrated in the following table.

Table 2. Anxiety Resulted from Lack of Preparation.

\begin{tabular}{lllll}
\hline Items & Statements & Scales & № & \% \\
\hline \multirow{4}{*}{9} & I start to [fear] panic when & SA & 76 & $49 \%$ \\
& I have to speak without & A & 58 & $37 \%$ \\
& preparation in my & UN & 0 & $0 \%$ \\
& [speaking] English class. & D & 12 & $8 \%$ \\
& & SD & 8 & $6 \%$ \\
22 & I don't feel pressure to & A & 10 & $6 \%$ \\
& prepare very well for & UN & 10 & $6 \%$ \\
& English classes. & D & 64 & $1 \%$ \\
& & SD & 68 & $42 \%$ \\
& I get nervous when my & SA & 50 & $32 \%$ \\
33 & English teacher asks & A & 70 & $45 \%$ \\
& questions Which I haven't & UN & 0 & $0 \%$ \\
& Prepared in advance. & D & 26 & $17 \%$ \\
\hline
\end{tabular}

$5=$ Strongly Agree (SA) 4= Agree (A) $3=$ Undecided (UN) $2=$ Disagree (D)

$1=$ Strongly Disagree $(\mathrm{SD}) \mathrm{f}=$ Frequency $\%=$ Percentage

As can be seen from Table 2, a large number of respondents agreed or strongly agreed with the question 'I start to feel fear when I have to speak without preparation in my speaking classes". For most of the students, being asked to speak without prior preparation appears to anxiety provoking situation of language learning. For example, Among 154 subjects of the study, 134 (86\%) of them strongly agreed or agreed that speaking without prior preparation causes them fear to speak when they are called to speak. Item (22) is also the indicator of the advantage of preparation for English classes. As it can be observed from Table 4 above $132(87 \%)$ students strongly disagreed or disagreed with item (22). It seems that students feel much pressure to prepare them for speaking classrooms. Unless they get prepared for speaking, they don't feel comfortable while to learn to speak. This implies that feeling of uneasiness and worry stems from lack of prior preparation.

Anxiety is experienced when students are asked to speak in an oral class without preparation is also considered in question 33. Almost three fourth of the participants $120(77 \%)$ endorsed that positively with being asked to speak in front of the students without being prepared in advance. They are fearful because they might not be familiar to the topic and tend to lose words to speak when they are asked to speak without preparation. As to the responses of the students, advance preparation seems to alleviate speaking anxiety.

From the data expressed by students, it is possible to say that many students felt frustrated due to being asked without prior preparation. In other words, students may lack readiness for English classes; they usually feel anxious when they are asked to speak English. Students have also suggested the importance of prior preparation in speaking classroom.

The data indicate that some students thought that if they understood the lessons' topic very well or clear instruction is given, they would participate in the classroom activities or would say a lot about that topic. If they did not understand the lesson, they kept silent. This implies that failure to be 
prepared and being not familiar with the topic plays a significant role in provoking speaking anxiety.

Teachers also complained that lack of readiness of their students for speaking classroom is the major problem that hampers their speaking skills and language learning. They stated that most EFL learners do not get ready to take part in speaking activities. As a result, teachers feel bored with speaking lesson and sometimes tend to teach other language skills. One of the teachers expressed:

...speaking lesson is boring because students are not ready to get prepared to take part in speaking activities. This may result from their previous language learning experience. They were highly devoted to teacher dominated language classroom where learners demand to speak was very less. I also doubt about language teachers competency in addressing the aim of language learning. As a result, students are [reluctant] and sit idly and we teachers tend to give less room for speaking lesson (Teacher 8).

Another teacher added

"...Grade ten students do not like to take part in speaking activities because they complain that they find only how of speaking on the national examination (only the grammar part)" (Teacher 1).

As it is evident from the information stated, many EFL learners give due attention to the form rather than meaning. It seems that the way national examination is prepared also shifted their attention toward the form of the language. This notion significantly affected their attitude toward speaking skills. As the result, they seemed that they ignored prior preparation for speaking classroom. It is apparent that from the responses of teachers and students, speaking without preparation seems quite stressful for a large number of students; therefore, they preferred to be well-prepared before speaking in the classroom. They sometimes want to skip the class or avoid active participation during the class. Preparation is considered as the strategy of overcoming anxiety about speaking.

In general, from the result of the findings, it is possible to infer that there is the problem in taking linguistic risks. Lack of risk taking caused communication failure for some students who thought that their English knowledge was insufficient or who did not understand the teacher or the topic. Therefore, they were not willing to participate in classroom activities because they felt anxious about making an error so they tried either to avoid it or took minimal risk. As a result, they face difficulty in verbal production which creates learners' fear of being called to speak in the class. Speaking without prior preparation could be threatening. According to MacIntyre and Gardner [15], highly anxious students should require more time to respond if they were able to compensate for their anxiety. This would imply that students of low ability need some preparation before expecting them to engage in oral tasks.

iii. Problems at Input Stage

This category presents the results about speaking anxiety caused as a result of problems students face at input stage of learning. Learners' direct source of information about the target language is the target language itself. When they come into direct contact with the target language, this is referred to us input. In FLCAS questions (4) "it frightens me when I don't understand what the teacher is saying in foreign language" and (29) "I get nervous when I don't understand every word the English teacher says" are to depict anxiety as a result of not understanding the message of the target language. Views of the students regarding the above questions are indicated below.

Table 3. Anxiety Generated by Problems at Input Stage.

\begin{tabular}{lllll}
\hline Items & Statements & Score & № & \% \\
\hline \multirow{4}{*}{4} & \multirow{4}{*}{ It frightens me when I don't } & SA & 56 & $36 \%$ \\
& understand what the teacher & UN & 76 & $49 \%$ \\
& is saying & D & 16 & $0 \%$ \\
& & SD & 6 & $41 \%$ \\
& \multirow{3}{*}{29} & SA & 44 & $29 \%$ \\
& I get nervous when I don't & A & 66 & $43 \%$ \\
& understand every word the & UN & 0 & $0 \%$ \\
& teacher says & D & 26 & $17 \%$ \\
& & SD & 18 & $11 \%$ \\
\hline
\end{tabular}

$5=$ Strongly Agree (SA) $4=$ Agree (A) 3= Undecided (UN) 2= Disagree (D) $1=$ Strongly Disagree $(\mathrm{SD}) \mathrm{f}=$ Frequency $\%=$ Percentage

Table 3 reveals that almost all of the subjects of the study experience speaking anxiety because they are unable to understand what the teacher is saying to express their idea. According to the scores, $132(85 \%)$ students strongly agreed or agreed with the idea that students feel uneasiness because they don't understand what the teacher is saying. Likewise, over two third of the participants endorsed positively item (29). This implies that most students worry about the incompressible input what the teacher is saying.

From the above results of the findings, students experience communication apprehensions when they fail to understand the message in the target language. From the scores, it can be suggested that anxiety is generated by incomprehensible input. At input stage difficulties may arise if the language spoken too quickly or if the material is presented in the form of complex sentences or in an ambiguous ways. They may also found difficulties in sound discrimination and understanding structures of the target language message. As a result, the whole process of learning will be affected. Anxiety at input stage restricts the anxious students to pay full attention to what their teacher says and reduce their ability "Onwuegbuzie et al [20]".

From the already mentioned information by students, it can be concluded that the students were frustrated when asked to speak English because they did not understand some or totally their teachers' questions or discussions. They justified their anxiety by the fact that they must concentrate on understanding the questions. In both questions the apprehension experienced by the students represented by expressions like nervous, frightens and I don't understand. The high score in both questions suggest that the anxiety generated by incomprehensible input. Failure to comprehend the target language is a major cause of speaking anxiety. 
With this regard, Horwitz et al [13] found that incomprehensible input is one of the major sources of anxiety when learners fail to understand target language messages.

(2). Fear of Negative Evaluation

This section presents the results related to the third category of the questionnaire used in this study which is fear of negative evaluation which is the worry over how one's action will be received by others in the social setting. It signifies apprehension over academic or personal evaluation on the bases of students' performance while using the target language. In using the target language in speaking classroom, students may think that they would be evaluated by their teachers or their fellow students. The result for fear of negative evaluation will be dealt with subcategories of fear of making mistakes and anxiety prone from error correction.

i. Fear of Making Mistake

This sub-section presents the results of fear of making mistakes while learning to speak English. Students' fear of being evaluated with making mistakes is considered through item (2) "I don't worry about making mistakes in speaking classroom". This question will provide information about views of students toward making mistakes in learning to speak and their feeling about being evaluated by others.

Table 4. Anxiety about Fear of Making Mistakes.

\begin{tabular}{lllll}
\hline Item & Statement & Score & № & \% \\
\hline \multirow{4}{*}{2} & & SA & 10 & $6 \%$ \\
& I don't worry about & A & 20 & $13 \%$ \\
& making mistakes in & UN & 0 & $0 \%$ \\
& Speaking English. & D & 58 & $38 \%$ \\
& & SD & 66 & $43 \%$ \\
\hline
\end{tabular}

$5=$ Strongly Agree (SA) 4= Agree (A) 3= Undecided (UN) 2= Disagree (D)

$1=$ Strongly Disagree $(\mathrm{SD}) \mathrm{f}=$ Frequency $\%=$ Percentage

As it is indicated in Table 4, most of the students strongly disagreed or disagreed with the idea that they do not worry about making mistakes. Among 154 students, 124 (81\%) made negative view to the idea. This suggests that students feel fear of making mistake in learning to speak English as foreign language.

In the light of the above scores of students, it can be concluded that almost all students are worried of making mistake because of being evaluated by their teachers or fellow peers. Students' fear is brought by the environment of the foreign language classroom, where they are consistently evaluated. It seems that when students fear being negatively evaluated they may experience anxiety at the output stage. One must note that those respondents who expressed their worry about making mistakes and being controlled by everyone in the class experienced forgetfulness and lack of concentration.

From the students' respondents, it can be inferred that fear of making mistakes provided considerable anxiety to the subjects. They are worried that others may evaluate them negatively. Learners may be sensitive to evaluation of their peers "Cubuku [5]". When students are fear of being evaluated their classroom participation will be affected.
Students with fear of negative evaluation might adopt the action of avoidance "Chan and $\mathrm{Wu}$ [4]". They also seem that they had negative attitude to making mistakes.

Through written reflection teachers also added,

"While teaching speaking activities most of my students develop frustration of being laughed at by other students. ... where there are so many students and teacher are present" (Teacher 1).

Another teacher added:

"fear of ridicule and criticism from both teachers and fellow students is the most dominant factor affecting students, participation in speaking classroom" (Teacher 8).

The result of the findings through the question and written reflection indicated that more than half of the respondents' classroom participation and language performance were affected with fear of making mistakes. It can be said that when students fear negative evaluations, they may experience anxiety at output stage or in language production. In the same vein, MacIntyre and Gardner [16] pointed out that fear of negative evaluation such as fear of making mistakes is closely related to communication apprehension. This impairs the quality of learners' language performance. In a language class the fear of making mistakes is so serious in some students who are practically determined to stay silent rather than risk committing a grammatical error "Dörnyei [8]". The result of anxiety within variables (table 4) also indicated that speaking anxiety mostly and caused by fear of negative evaluation and the seriousness of anxiety was very high with fear of negative evaluation which was almost equal to 4.00.

In general, it can be concluded that the majority of students were afraid of the perceptions of others feedback or being evaluated by others when to learn to speak English. With a percentage of $81 \%$, perceptions of others evaluation are placed as the major cause of speaking anxiety. Most of the students were concerned about various kinds of evaluative situations in which their knowledge and performance of English will be monitored by the teacher and their fellow students. Some are afraid of making mistakes in terms of grammar, arranging words and their perceived lack of knowledge about the class subjects that they were studying. As a result, students may sit passively or withdraw from classroom activities. They may not consider errors as a natural part of the learning process. Consequently, fear of making mistake affects students' language production which in-turn affects their language performance and competency.

ii. Error Correction

This part presents the data gathered through questions aimed to depict students understanding of error correction and way of being corrected. Failing to understand the teacher's correction and worry about teachers errors correction are considered through question (15) "I get upset when I don't understand what the teacher is correcting" and (19) "I am afraid that my English teacher will correct every mistake I make" of the questionnaire presented for students under the category of fear of negative evaluation. 
Table 5. Anxiety about Fear of Error Correction.

\begin{tabular}{lllll}
\hline Items & Statements & Scales & № & \% \\
\hline \multirow{4}{*}{15} & & SA & 62 & $40 \%$ \\
& I get upset when I don't & A & 62 & $40 \%$ \\
& understand what the & UN & 0 & $0 \%$ \\
& teacher is correcting. & D & 16 & $10.5 \%$ \\
& & SD & 14 & $9.5 \%$ \\
& & SA & 62 & $40 \%$ \\
& I am afraid that my & A & 70 & $45 \%$ \\
& English teacher will & UN & 0 & $0 \%$ \\
& correct every mistake I & D & 14 & $9 \%$ \\
& make & SD & 8 & $6 \%$ \\
\hline
\end{tabular}

5= Strongly Agree (SA) 4= Agree (A) 3= Undecided (UN) 2= Disagree (D)

$1=$ Strongly Disagree $(\mathrm{SD}) \mathrm{f}=$ Frequency $\%=$ Percentage

As can be seen from the students' response for the idea that students get upset when they don't understand what the teacher is correcting, $124(80 \%)$ agreed or strongly agreed with it. The scores of the students suggest that they are worried when they don't understand teacher's correction. This type of anxiety stems from incomprehensible error correction. It seems that the way the teacher gives them correction may not be clear to help them improve their wrong doing. Likewise, with the question (19) "I am afraid that my English teacher is ready to correct every mistake I make" specifically students endorsed that they feared the teachers 'evaluation. As it is depicted, $132(85 \%)$ students strongly agreed or agreed that they afraid they would be given correction for each of the error they had made. It seems that correction may be given spontaneously.

The scores of the findings revealed that students are frustrated when the teacher corrects every error they make. The score indicated that being interrupted each time they spoke would increase their tension and may lead to lack of concentration. Meanwhile, the score implies that learners experience anxiety when they fail to grasp the correction given by the teacher.

In the light of the above responses, students suggested that correction could be important and beneficial at the end of one's speech. The responses revealed that students are stressed from spontaneous error correction. When they are corrected soon they make mistakes, they think that they are doing wrong. This may result from teachers' way of handling and feeling to error correction.

From this reflections, it can be inferred that most students feel worry by the evaluation given by their teachers and fellow students. They suggested that error correction is given subsequently by their teachers and students may laugh at them. They consider that they might be underestimated by their classmates. It seems that students feel uneasiness with being corrected by their teacher and fellow students because they may be laughed at by others.

Teachers' reflection through written reflection also indicated that teachers' way of error correction may contribute to speaking anxiety. For example, one of the teachers said "teacher's dependence on error prevention is a cause for learners speaking anxiety" (Teacher 9).
Such comments might be a clear indication that language learners feel inhibited and reluctant when they receive constant corrections each time they speak. As the findings indicated the view of students toward error correction and the way error was given was another anxiety provoking in the process to learn speaking in EFL classroom. The result also suggests that teacher's view to error correction is another situation affecting students' speaking skills.

One must note that those students who express their worry about making mistakes and being controlled by everyone in speaking classroom experience forgetfulness and lack of concentration as a result of the fact that fear of making mistake provokes speaking anxiety. It can be said that committing error in front of the student and the teacher is considered as anxiety provoking issue among the students. In the same vein, MacIntyre and Gardner [16] pointed out that fear of negative evaluation such as fear of making mistakes is closely related to communication apprehension.

\section{(3). Competitiveness}

In this sub-category, the result that indicates fear of being less competent than other peers is presented. Questions (7) "I keep thinking that the other students are better at speaking English language", and question (23) "I always feel that the other students speak the language better than I do", of FLCAS are items depicting anxiety raising competitiveness. Accordingly, the data gathered from the above questions are presented in the following table.

Table 6. Anxiety as a Result of Competitiveness.

\begin{tabular}{lllll}
\hline Items & Statements & Scales & № & \% \\
\hline \multirow{4}{*}{7} & SA & 58 & $38 \%$ \\
& I keep thinking the other & A & 72 & $47 \%$ \\
& students are better at & UN & 0 & $0 \%$ \\
& speaking English that I am. & D & 16 & $10 \%$ \\
& & SD & 8 & $5 \%$ \\
\multirow{2}{*}{23} & SA & 68 & $44 \%$ \\
& I always feel that the other & A & 64 & $42 \%$ \\
& students speak English & UN & 0 & $0 \%$ \\
& better than I do. & D & 11 & $6 \%$ \\
& & SD & 12 & $8 \%$ \\
\hline
\end{tabular}

$5=$ Strongly Agree (SA) $4=$ Agree (A) $3=$ Undecided (UN) $2=$ Disagree (D) $1=$ Strongly Disagree $(\mathrm{SD}) \mathrm{f}=$ Frequency $\%=$ Percentage

As can be seen from Table 6, 130 (85\%) students agreed or strongly agreed with the idea that they keep thinking that other students are better at speaking English language than they are. Likewise, among 154 participants 132 (86\%) agreed or strongly agreed with the item "I always feel that the other students speak the language better than I do".

In their responses to these two items, students indicated that they consider their speaking ability was poor compared to their fellow peers and fear being less competent than others. They suggested that the main source of their nervousness when they speak English seems to be perceptions of their incompetency in speaking the target language. As a result, they are frustrated to speak in front of these students they think are better than them. With this 
regard, Horwitz et al [13], claims that most of the students' speaking anxiety comes from their self-concept abilities. Therefore, it can be concluded that learners' low selfperception of speaking ability is a cause or source of anxiety in speaking classroom.

In general, students feel that they must not less competent than their fellow peers. According to the result obtained from question 3 of written reflection that over self comparison to other classmates appeared to be the most frequent aspect related to competitiveness.

On the basis of the data, one can sense that overt self comparison is the main phenomena for their fear of speaking in the classroom. Bailey study [3] found that learners' competitiveness natures can act as a source of anxiety. The results of the findings suggested that they must not be less competent than their fellow peers because their level was approximately the same. It also suggested that most students would feel nervous when their peers performed better. Young [24] found that anxious students thought their speaking skills were weaker than their peers and they were looking down at them.

As the results of the findings indicated, most of the students make self criticism which does not help them in learning to speak English and hamper their speaking skills. As suggested by Horwitz et. al [13] self-criticism could be interpreted as one of the sign of anxiety resulting from constant comparison to the others such as peers.

In general, students seem to have experienced communication apprehension and fear of negative evaluation as a result of their experience they had from speaking classroom and self perception. This is from their view to error correction by their teachers and peers and lack of confidence. Regarding this Macintyre and Gardner [16] stated that communication apprehension and fear of negative evaluation emerge due to negative experience in speaking that is of teachers' feedback, their participation in the classroom and their peers comment.

\section{(4). Oral Test Anxiety}

This category presents the feeling of EFL learners being failed with speaking tests. It illustrates In FLCAS, oral test anxiety as a predictor of speaking anxiety was to be explored through questions (8) 'I am usually at ease during oral [speaking] tests in my English class", (10) "I worry about the consequence of failing my speaking test." And (21) "the more I prepared myself for an oral test, the more confused I get".

Table 7 depicts that more than half of the students were strongly disagreed or disagreed with the idea that students are usually at ease during speaking tests in their English classroom. For example, among 154 subjects of the study, $118(77 \%)$ of them strongly disagreed or disagreed with question (8). They endorsed that English exams especially speaking tests were anxiety provoking situations for them. It seems that they feel discomfort with oral test of English. They indicated that students may fear oral tests because of its demanding nature.
Table 7. Anxiety as a Result of Failing Oral Test.

\begin{tabular}{|c|c|c|c|c|}
\hline Items & Statements & Scale & № & $\%$ \\
\hline \multirow{5}{*}{8} & \multirow{5}{*}{$\begin{array}{l}\text { I am usually at ease during } \\
\text { speaking tests in my English } \\
\text { classroom. }\end{array}$} & SA & 14 & $9 \%$ \\
\hline & & A & 20 & $13 \%$ \\
\hline & & UN & 2 & $1 \%$ \\
\hline & & $\mathrm{D}$ & 68 & $44 \%$ \\
\hline & & SD & 50 & $33 \%$ \\
\hline \multirow{5}{*}{10} & \multirow{5}{*}{$\begin{array}{l}\text { I worry about the } \\
\text { consequences of failing } \\
\text { speaking tests. }\end{array}$} & SA & 64 & $42 \%$ \\
\hline & & A & 62 & $41 \%$ \\
\hline & & UN & 0 & $0 \%$ \\
\hline & & $\mathrm{D}$ & 20 & $12 \%$ \\
\hline & & SD & 8 & $5 \%$ \\
\hline \multirow{5}{*}{21} & \multirow{5}{*}{$\begin{array}{l}\text { The more I study for } \\
\text { speaking test the more } \\
\text { confused I get. }\end{array}$} & SA & 14 & $9 \%$ \\
\hline & & A & 8 & $5 \%$ \\
\hline & & UN & 2 & $1 \%$ \\
\hline & & $\mathrm{D}$ & 68 & $44 \%$ \\
\hline & & SD & 62 & $41 \%$ \\
\hline
\end{tabular}

$5=$ Strongly Agree (SA) 4= Agree (A) 3= Undecided (UN) 2= Disagree (D) $1=$ Strongly Disagree $(\mathrm{SD}) \mathrm{f}=$ Frequency $\%=$ Percentage

In addition, students revealed that they feel worry about the consequences of failing in speaking tests. Almost all students verified through their response that they worry when they fail oral tests. Among 154 students, 126 (83\%) of them strongly agreed or agreed with the view that they feel worry with the consequences of failing oral tests. It seems that the consequences of poor performance in oral tests lead to negative expectation toward speaking English and English classes. It seems that with negative expectation and attitude of students' language performance and competency may be affected.

However, for the question 'the more I study for speaking tests (oral tests) the more confused I get', students indicated that they do not get confused with preparation for oral tests. Among 154 subjects of the study, 130 (85\%) of them strongly disagreed or disagreed with the idea. This implies that prior preparation for oral tests exerts a considerable effect in order to ease speaking anxiety. From the responses of the students, it seems that students feel comfort with being ready for speaking tests. Accordingly, anxiety that may result from speaking test contexts may be alleviated by prior preparation.

The data gathered through interview with teachers also strengthen the above idea. Teachers have indicated that when learners fail to succeed in their oral tests, these students lack motivation to participate in normal speaking activities in the class. They declared that even clever students show this kind of behavior. They explained that because of poor performance in the previous oral test, unpleasant test experience from either language class in general and speaking test lead students to transplant the unhappy image to the present oral test unconsciously. The teacher also indicated that test-anxious students often put "unrealistic demands" on themselves and feel that anything less than a perfect test performance is a failure (Teacher 2).

Another teacher who is the subject of the interview added that English language teachers at elementary level usually emphasize grammar activities paying less attention to other language skills, especially evaluating speaking skills of their 
students. As a result, when learners are asked to speak in front of the class in the high school they face difficulty. In case of oral test it is difficult for them to make a sentence standing in front of their peers. As a result, their language performances are not satisfactory and eventually hate the class (Teacher 1).

With this regard one of the teachers reflected his view through written reflection that their concept of communicative language teaching may affect the way of teaching. He reflected:

...mostly language teachers in our school depend primarily on grammatical explanation rather than on communicative proficiency. Consequently, students prefer to attend structures and form more than meaning. In this case, I don't think we have good awareness about the need to incorporate traditional concept of language teaching into the modern communicative approach (Teacher 8).

From the above views of students and teachers, it can be said that the notion "I failed before, I will fail again" is the main cause of learners speaking anxiety. It seems that poor performance with previous oral tests exerts a significant role in ones speaking anxiety. Likewise, as it is indicated, the awareness teachers had about communicative language teaching approach may contribute to students' fear of speaking tests which in turn affects students speaking skills.

In the light of the above data gathered from the subjects of the study, it can be said that students can be so worried when they fail to perform in their oral classes or when their efforts do not lead to improve their overall result regarding oral test. Foss [10] found that language learners might adopt avoidance behavior because they judge their capabilities in the new language to be so poor. The frustration about expecting continued failure is high within the subjects of this study.

(5). Other Causes of Speaking Anxiety

This part deals with the last category of the questionnaire (FLCAS) which is named as other causes of anxiety from English classroom and other problems frequently raised by respondents (teachers and students) of written reflection and interview.

i. Participants' Attitude to Speaking Anxiety

This part concerned about the participants' attitude toward speaking English, such as how important they think it is to learn to speak English and how much they enjoy speaking it. Ones' beliefs about language learning may contribute to anxiety or tension in language classroom. In FLCAS items like (5) "It wouldn't bother me at all to speak English and (30) "I feel anxious by the number of rules you have to learn to speak the foreign language," are used to examine learners' beliefs about speaking English and their speaking anxiety. The second item is aimed to see learners' consideration of language accuracy in learning to speak foreign language in front of the class. According to Horwitz et al [13], overstressing the importance of the target language accuracy can contribute to anxiety in language learning.
Table 8. Anxiety Resulted from Participants Attitude to Speaking.

\begin{tabular}{lllll}
\hline Items & Statements & Scales & № & \% \\
\hline \multirow{4}{*}{5} & & SA & 6 & $4 \%$ \\
& It wouldn't bother me at all to & A & 54 & $35 \%$ \\
& [speak] English classes. & UN & 0 & $0 \%$ \\
& & D & 56 & $36 \%$ \\
& & SD & 38 & $25 \%$ \\
30 & I feel anxious by a number of & A & 58 & $38 \%$ \\
& Rules you have to learn to & UN & 0 & $42 \%$ \\
& speak English language. & D & 18 & $12 \%$ \\
& & SD & 12 & $8 \%$ \\
\hline
\end{tabular}

5= Strongly Agree (SA) 4= Agree (A) 3= Undecided (UN) 2= Disagree (D)

$1=$ Strongly Disagree $(\mathrm{SD}) \mathrm{f}=$ Frequency $\%=$ Percentage

This table shows that among 154 students 60 (39\%) of them strongly agreed or agreed with the idea that it wouldn't bother the students to take more speaking classes. This data indicates that almost half of the students were not worried to take more English classes. It shows that some students of EFL learners hate to attend more speaking classes. Learners seem to adopt negative attitude to speak English language. Such beliefs may stem from the demanding nature of speaking classroom. This unrealistic belief seems to cast a considerable influence upon the ultimate achievement and performance in the target language.

The table clearly indicates that $122(80 \%)$ students viewed that they were worried to keep rules of the language while speaking the target language. This may be generated from the desire to speak correctly. The result of the findings indicated that since some language learners' believe that they must speak the foreign language correctly, they were fearful to use the language. However, the aim of current language teaching, which is communicative language teaching (CLT), language learners are required to communicate with the target language (EFL) before accuracy is attained.

From the above responses of students, one can note that unrealistic conception about language learning can be a source of anxiety in learning English as a foreign language. Most students believe that others may underestimate or may be called lazy because they seek for help. Such beliefs cast a considerable influence up on the ultimate objectives of language learning which is endowing learners with fluency. The results of the existing researches also support this idea. For example, Horwitz et al [13] believe that any performance in L2 is likely to challenge an individual's self-concept as a competent communicator, which may lead to embarrassment. According to Young [24: 428], erroneous beliefs about language learning can contribute greatly to creating language anxiety in students. Ohata [19] explained that unrealistic beliefs can lead to greater anxiety and frustration, especially when the beliefs and reality clash.

Language teachers also strengthen this idea as follows.

...some language students may need assistance from their teacher in learning to speak, but do not ask for help because they might view help seeking either from the teacher or their peers as the sign of weakness, immaturity or even incompetence. All students, except very few, do not ask their 
teachers for help during to learn to speak (Teacher 4).

From the above scores of the teacher, it can be said that English language learners become anxious because of their own negative feelings toward the target language and their bad feeling to know something. Horwitz, [13] has indicated that certain beliefs about language learning contribute to students' tension and frustration in the class. Moreover, such kind of unrealistic perceptions or beliefs on language learning and achievement can lead to frustration toward students own poor performance in a foreign language. Macintyre and Gardner [16] argue that negative expectations lead to cognitive interference which produces performance deficits. Poor performance and negative emotional reactions further reinforce the arousal of debilitating anxiety.

ii. Anxiety from Personal Problems

This theme elicits about anxiety that may occurs as a result of personal problems related to an individual students. In FLCAS, questions (6) "During speaking classroom, I find myself thinking that have nothing to do with the lesson" and item (12) "In the speaking class, I can get so nervous when I forget things I know" are indicators of students personal problems related to lack of concentration and forgetfulness. The results are illustrated in the following table.

Table 9. Some Anxiety Related to Behavior.

\begin{tabular}{lllll}
\hline Items & Statements & Scales & № & \% \\
\hline \multirow{4}{*}{6} & & SA & 24 & $16 \%$ \\
& During speaking class, I find & A & 56 & $37 \%$ \\
& myself thinking that have & UN & 2 & $1 \%$ \\
& nothing to do with the lesson. & D & 40 & $25 \%$ \\
& & SD & 32 & $21 \%$ \\
\multirow{3}{*}{12} & In the speaking class, I can get & SA & 44 & $29 \%$ \\
& so nervous when I forget things & UN & 76 & $49 \%$ \\
& I know. & D & 12 & $8 \%$ \\
& & SD & 20 & $13 \%$ \\
\hline
\end{tabular}

$5=$ Strongly Agree (SA) $4=$ Agree (A) $3=$ Undecided (UN) $2=$ Disagree (D) $1=$ Strongly Disagree $(\mathrm{SD}) \mathrm{f}=$ Frequency $\%=$ Percentage

As can be seen from Table 9, more than half of the participants strongly agreed or agreed with item (6). 80 (53\%) indicated that they have a positive view toward thinking things that have nothing to do with the lesson. From the scores of the students it can be said that more than half of the students lack concentration while learning to speak. They seem that they may be busy with things not related to the topic of the lesson. Learners tend to put some unrelated demands on themselves when speaking foreign language.

In addition, in Item (12), forgetfulness is put as one of the cause of anxiety. As shown in table 9, 120 (78\%) of students endorsed the idea that they feel uncomfortable when they forget to say things they know positively. Almost all students verified that they strongly agreed or agreed with being anxious when they forget things they know in speaking foreign language. The result indicates that many students might felt anxious when they fail to speak because of concentration and forgetfulness.

Language teachers also share the above idea that students become anxious because of lack of concentration. Many teachers indicated that EFL learners lose concentration while learning to speak. For example, one of the teachers reflected:

...in speaking classroom many students are seen doing unrelated activities. They seem that they are participating genuinely but talking about things not related to the topic. ...though this is common in English classroom, it is seen boldly in speaking classroom. (Teacher 8).

Another teacher added:

...Some students keep on doing disciplinary works such as murmuring and doing unnecessary things. ...When such students are asked to speak in the class they are unwilling to say a word teacher in front on their friends (Teacher 1).

The results of the above data indicate that in speaking classroom most EFL learners are not following the lesson attentively. They are confused with speaking lesson when they are present physically and absent mentally. Likewise, forgetfulness is investigated as one of anxiety provoking situation in learning to speak.

From the above results of the findings it can be inferred that lack of concentration and forgetfulness might arose speaking anxiety. These causes may stem from vocabulary inadequacies and fear of making mistakes. Similarly, forgetfulness and lack of concentration seem to be related to personal behavior and conceived beliefs. Personal behaviors and conceived beliefs related to classroom language learning may provoke anxiety.

iii. Accuracy of Pronunciation

This theme depicts the fear students had about their pronunciation while speaking English. Although the accuracy of pronunciation is not included in FLCAS, participants of written reflection (students and teachers) subsequently discussed through written reflection and interview about the worry they had about their pronunciation in their speaking classroom. This indicates that the relationship between anxiety and pronunciation is another issue that has been raised by the subjects of the study. For example, (student 13) explained:

...in speaking foreign language in front of the classroom I assume that my way of pronouncing words is fragile. This is because of the relation between the ways some English words written and pronounced has made me confused. ...this created [self-consciousness] in me to pronounce words in front of my fellow peers. As a result, since I fear to pronounce those words and I decide not to say words.

Another student added

"I am worried about my pronunciation when I speak English. The written word is quite different from what we here from our teacher" and added "learning pronunciation is not seen at our level" (Student 11).

From the responses of the students, we can say that students fear to say English words because of their poor understanding of the relationship between the word and the way it is pronounced. Likewise, the students mentioned that the difficulties pertain to immediately linking the word they hear from their teacher. It seems that since students are not aware of the way words are pronounced, pronunciation is not 
considered as the element of language learning. Likewise, anxious learners have trouble distinguishing between the target language's sounds and structure. When the target language is spoken by his/her teacher, students reported that they want to only hear a loud buzzing sound "Horwitz et al., [13]". Also reported by Horwitz et al. [13], many students, who experience foreign language learning anxiety, claim to understand little to none of the teacher's output.

Regarding the above views, teacher respondents of written reflection indicated that pronunciation appeared as a big cause of stress for ESL learners. In this regard one of the teachers directed:

...our students fear in speaking foreign language because of the weak relationship between some English words and the way they are spelt and teaching pronunciation at this grade level (grade ten) is a forgotten area (Teacher 7).

Another teacher strengthens this:

...our students think as there is close relationship between written and spoken English when words are pronounced. The moment I give them correction to the word misspelled they start to tremble and unable to speak. Those students won't appear again in classroom participation. ...for this reason learners fail to recognize the spoken form words by their teacher that they know precisely in a written form. As a result, they frustrate to say words in front of the class. ...teaching pronunciation is not given due attention in high school (Teacher 2).

Respondents (teachers and students) suggest that accuracy of pronunciation was indeed one of the major concerns of stress in speaking English. In addition, students understanding about the way words are pronounced matters in speaking foreign language. They did normally worry about their pronunciation to speak in classroom. They typically realized that they were not sure how to pronounce some of the words in learning to speak English. Students are not aware of the way words are pronounced. This in turn affected their oral proficiency in learning English as a second language because they felt that they do not have adequate oral proficiency to explain their idea clearly. It also exerts a significant influence on students' language performance.

From the overall data, it seems that pronunciation is an important issue across language learners because of its immediate effect on interaction. Price study [22] also indicated that learners are afraid of making pronunciation error in English classroom. They indicated that they are really afraid of some words of English. They may not pronounce as their teacher does. In general, they feel difficulty particularly when pronouncing those sounds that they never have produced or even heard before.

iv. Knowledge of Vocabulary

This section presents about the problems related to speaking anxiety as a result of inadequacy of vocabulary. In written reflection, many students frequently raised that limited knowledge of vocabulary as a major issue aggravating anxiety while to speak English in the classroom. Where academic achievement is concerned knowledge of vocabulary is a predictor of academic achievement EFL learners. In this regard, the subjects' responses to the question (3), "what causes you anxious during speaking English in front of the classroom?" indicated that they experience difficulties in remembering and retrieving vocabulary. One of student's reflected:

...I don't have exact words to express my idea. Sometimes I am [conscious] I am not using the right word. I always feel [nervous] speaking English because I don't have enough vocabulary. Sometimes I lose words I want to say (Student 5).

Another student also indicated:

...I don't have exact words to express my idea while I am asked to speak about certain topics. The moment I am to be called by my teacher I feel empty minded. Sometimes I am [unconscious]. ...I am not using the right word. I always feel nervous speaking English because I don't have enough vocabulary (Student 9).

Student 5 indicated that he experiences difficulties in remembering and retrieving vocabulary. Inability to recall vocabulary items play a significant role for their fear in speaking. Similarly, limited knowledge of vocabulary was another problem they revealed. They revealed that lack of vocabulary is the main cause for their worry in speaking classroom.

Teachers also reflected that limited knowledge of vocabulary is another problem for their students' feel of fear to speak in front of the class. One of the teachers said "possessing limited stock of vocabulary is assumed as the cause of learners speaking anxiety" (Teacher8).

The subjects (teachers and students) reported that many words do not come out when required to speak. Therefore, it can be deduced that limited knowledge of vocabulary and unable to recall the existing words from memory seem to play a significant role in provoking learners' speaking anxiety. Learners with limited knowledge of vocabulary experience incomprehensible output which may affect the whole processes of language learning. It seems to affect learners' language achievement and performance.

v. Lack of Exposure to the Target Language

This part of the study presents the responses of participants (students and teachers) regarding lack of experience with the target language. They suggested that lack of exposure to the target language contributed a significant role in speaking anxiety. For example, one of teachers reflected:

...lack of exposure and practice, speaking English is confined to the classroom. Even students sometimes tend to use their mother tongue to express their idea in English classroom. ...generally in our country, no one can be seen speaking English any where rather than in class where English is used as a medium of instruction. ...in English classroom sometimes students are forced to use their mother tongue. This has also intensified frustration to speak English in English classroom (Teacher 1).

Another teacher added:

... Obvious those teachers do not sufficiently motivate their students to enable them engaged in communicative learning experiences. If we closely look at what is going on in the school context, it will be far behind the truth to say that we 
are helping our students to use the language. Moreover, when students see that the teacher himself is not good enough in communicative competence such as fluency and acceptable language use, they presumably feel de motivated and thus fail to experiment with the language (Teacher 8).

Data obtained from teachers indicates that students are rarely practice with the target language in the classroom. Moreover, teachers do not motivate students to practice with English. As a result, they fail to use the target language when they are asked to speak. According to the information, it seems that the competence of the teacher is another anxiety provoking situation. Students also expressed that limited practice with the target language especially in English classroom is a serious problem in the development of their communicative competency which is troubling when they are required to speak.

One of the students expressed:

...we could rarely practice English only in the class during English classroom, out of the classroom no practice at all, lack of chance or practice ... trouble when you find a chance to speak (Student 7).

As (Student 4) explained:

...our English teacher expects us to speak the language fluently. ... we have no experience yet...our experience may be to speak only when the teacher asks to speak but not only other time.... These different practices in the classroom, I know, are very upsetting for us (Student 9).

It is clearly indicated that students come across traditional language teaching in which they were provided everything from their teacher and there was no chance to practice the target language. It is indicated that language teachers assume learners as fluent speakers but they still need to practice with the target language.

The result of the findings obtained from written reflection indicated that exposure to the target language was found a contributing factor responsible for negative effect on their speaking skills. The use of communicative language teaching approaches demand students to speak English who may not be used to it in their previous learning experience and therefore feel stress when they are called up on to answer questions or make oral activities in front of the classroom.

vi. Previous Learning Experience

This category of the findings presents the responses given by respondents about their previous language learning experience. It is indicated that Students' poor background which goes with their past experience was seen to be the cause for their present speaking anxiety. One of the students reflected:

...starting from my elementary school I haven't been practicing English language through speaking it and only I come across for one period a day since other subjects were not given in English (Student 8).

Another student also viewed:

...because the class was teacher dominated throughout the period, I didn't have time to practice English in my early elementary school. The consideration given by my English teacher to allow us practice speaking English was not adequate and not initiative to use the language in classroom as well outside the classroom (Student 7).

From the above data, it can be observed that students have come across traditional language learning approach in which the teacher dominates every activity in the classroom. It seems that they had had no exposure of practicing with the target language. They suggested that oral practice in the classroom with the target language was not emphasized by their teachers. Teachers may adequately focus on grammar and look to prepare students for exams.

Teacher respondents of interview have declared that learning foreign language in use is a forgotten skill not only in elementary level but also in high school level. For example, one of teachers reflected:

...I sometimes stop teaching speaking activities and deal with other skills because students are extremely reluctant in practicing to speak. I usually bored with speaking lesson which is the result of their previous learning experience. (Teacher.1)

Teacher 8 added:

...most language teachers depend on primarily on grammar explanation rather than on communicative proficiency. What we do in the school is preparing students for exams at the expense of fostering the necessary language skills. This in turn has led to students having little understanding about the value of the second/ foreign language in a meaningful way.

From the above scores, it can be inferred that their exposure in previous learning experience has a significant effect on learners' language competency. This indicated that there was little intensive training academic oral presentation in the context during their elementary classes. It is also possible to deduce that speaking activities was not given due attention in their previous classes. Macintyre and Gardner [15] argue that unsuccessful and negative experience in the past led to high level of anxiety on learners. This confirms that when learners are not exposed to language learning through use in their past experience, they may highly experience speaking anxiety.

To sum up, the above sub-topics of the current study focused to address causes of speaking anxiety to EFL learners. Accordingly, lack of self-confidence in using the target language, under preparation or lack of prior preparation and incomprehensible input were investigated as a great contributor to speaking anxiety. Further analysis of data revealed that fear of making mistakes and feedback from their teachers and peers were the biggest anxiety provoking situations in learning to speak English (Table 4). Competitiveness, or peer pressure, oral test anxiety, learners' attitude toward the target language, personal problems in language classroom, poor pronunciation, limited knowledge of vocabulary and lack of practice (limited opportunity to practice the target language were situations that escalating learners speaking anxiety in EFL classroom. The overall findings indicated that the participants are extremely worried about making linguistic mistakes and lacking linguistic 
knowledge including grammar, vocabulary, and pronunciation. This result is in line with most of the previous studies "(Akkakoson, [2]; Ahmed, [1]; Diaab, [7]; Han et al. [12]".

\section{Summary, Conclusions and Recommendations}

This chapter presents the summary, conclusion of the findings and recommendations

\subsection{Summary}

This study tried to assess causes and of learners' speaking anxiety in EFL classroom with reference to grade nine at Mizan Secondary and preparatory School in Bench Maji Zone in SNNPR. In order to address the above objective of the study, research questions were raised. Questionnaire, written reflection and interview (semi- structured interview) were used as data gathering tools in the current study. This research design was required because social phenomena are so complex and different kinds of methods are needed to best understand these complexities. The subjects of the study were one hundred fifty four grade nine students and eleven English language teachers who were teaching English in MSPS. Purposive and systematic sampling techniques were used to select the sample respondents and purposive sampling to select the school. To this end, the findings were analyzed, discussed and described quantitatively and qualitatively.

\subsection{Conclusions}

In brief, this study investigated some of the major causes of foreign language speaking anxiety among grade nine students. As mentioned above, there are several causes of foreign language speaking anxiety among which communication apprehension was the significant one because of their low self-confidence, lack of prior preparation and problem at input stage of learning. As it can be seen from the result of the findings students were afraid to make mistakes in learning to speak foreign language. These students seem to feel constantly tested and to receive every correction as a failure. It was also found that the feelings of anxiety become more threatening when the language instructors' manner of error correction is rigid and humiliating. The result indicated that competitiveness was another problem to provoke anxiety in learning to speak foreign language. In addition, the consequences of failing oral test were another considerable cause of speaking anxiety. Subjects of the study verified that they developed the notion of "I failed before, I will fail again". As it is indicated, participants' attitude to speaking classroom, lack of concentration and forgetfulness, Pronunciation, limited knowledge of vocabulary, lack of exposure to the target language (poor language learning background), were found anxiety provoking situation.

\subsection{Recommendations}

Based on the conclusions drawn, the following recommendations have been proposed.

i. Language teachers should work on escalating selfconfidence of the students in their language abilities. They may enhance self-confidence by encouraging and positive reinforcement. For example, providing appraisal (facial expression) for any of their accomplishment to learn speaking. Encouragement can explicitly make learners aware of their language abilities.

ii. Students should get prepared before the classroom. In addition, instructions, questions and activities at input stage should be given clearly and precisely.

iii. Students should be aware of the purpose of making mistakes in ones language proficiency or in an attempt of striving to fluency. Fluency can be achieved through making mistakes. Since 'errorlessness' in speech is far beyond reaching, students need to be reminded the value of making mistakes in language learning.

iv. Students should know that being corrected by their teachers and fellow students will help them in developing ones language competency. Therefore, teachers should create awareness about being corrected. They should provide error correction as wisely as possible since consistent way of error correction creates negative attitude to students. This does not mean that teachers should tolerate mistakes of all sorts.

v. Teachers should promote cooperative activities which allow anxious learners to practice the target language. It also provides learners with social skills that facilitate team work and enhance communication.

vi. Teachers should work on activities lowering anxiety in oral practice. For example, in the selection of topics they should give attention to students' knowledge of the world because unfamiliar topics may create lack of interest in students. Besides, clear and precise instructions should also be given for students.

vii. It is also recommended that teachers should confront students' erroneous and irrational beliefs by cultivating in them reasonable commitments for successful language learning.

viii. Teachers should give emphasis to incorporate elements of pronunciation teaching in their daily activities and should help students practice how words are spelt.

ix. Students should be given instructional efforts to be taught vocabulary. Before speaking activities are kept on certain topics, vocabulary practice related to the topic should be exercised. When vocabulary practice is integrated to speaking activities it is helpful for students who suffer from vocabulary inadequacies in speaking foreign language. Language teachers should 
adopt to provide students with more chances to practice their speaking skills.

x. Students should take part in speaking activities.

xi. Teachers should provide their students simple activities in group or in pairs and proceed to making speech in target language.

xii. Teachers should try to create safe learning environment so as to make the language classroom enjoyable and effective. Ely [9] indicated that before some students can be expected to take linguistic risks, they must be made to feel more psychologically comfortable and safe in their learning environment. As students come to feel more secured, they can then be encouraged to assume a more active role in the classroom.

\section{References}

[1] Ahmed, N. F. (2016). An exploration of speaking anxiety with Kurdish University EFL learners. Journal of Education and Practice, 7(27), 99-106.

[2] Akkakoson, S. (2016). Speaking anxiety in English conversation classrooms among Thai students. Malaysia Journal of Learning and Instruction, 13, 63-82.

[3] Bailey, K. M. (1983). Competitiveness and anxiety in adult second language learning: Looking at and through the diary studies. In H. W. Seliger \& M. H. Long (Eds.), Classroom oriented research in second language acquisition. Rowley, MA: Newbury House.

[4] Chan, D. Y. C. \& Wu, G. C., 2004. A Study of Foreign Language Anxiety of Elementary School EFL Learners in Taiwna. The proceedings of the 2000 educational academic conference in National Taipei Teachers College (pp. 85-100).

[5] Cubuku. F., 2007. 'Foreign Language Anxiety'. Iranian Journal of Language Studies, Vol. 1(2) pp 133-142.

[6] Daly, J. A. (1991). Understanding communication apprehension: An introduction for language educators. In E. K Horwitz \& D. J. Young (Eds.), Language Anxiety: From theory and research to classroom implications (pp. 3-13). Englewood Cliffs, NJ: Prentice Hall

[7] Diaab, S. (2016). Role of faulty instructional methods in Libyan EFL learners' speaking difficulties. Procedia - Social and Behavioral Sciences 232, 338-345.

[8] Dörnyei, Z., 2001. Motivational Strategies in the Language Classroom, Cambridge: Cambridge University Press. (Accessed on December 10/2010).

[9] Ely, C. M., 1986. 'An Analysis of Discomfort, Risk Taking, Sociably and Motivation in L2 classroom'. Language Learning, 36(1), 1-24.

[10] Foss, K. A., A. C., Reitzel, 1988. 'A Relational Model for Managing Second Language Anxiety'. TESOL Quarterly, 22:3 (437-454).
[11] Gerencheal, B. (2016). Gender differences in foreign language anxiety at an Ethiopian university: Mizan-Tepi University third year English major language learners in focus. African Journal of Education and Practice, 1(1), pp 1-16. https://www.iprjb.org/journals/index.php/AJEP/article/view/6 5

[12] Han, T., Tanriöver, A. S. \& Şahan, Ö. (2016). EFL students' and teachers' attitudes toward foreign language speaking anxiety: A look at NESTs and Non-NESTs. International Education Studies, 9(3), 1-11.

[13] Horwitz, E. K., 1986. 'Preliminary Evidence for the Reliability and Validity of a Foreign Language Anxiety Scale'. TESOL Quarterly 20(3):559-562.

[14] Horwitz, E. K., M. B, Horwitz, and J. Cope, 1986. 'Foreign Language Classroom Anxiety'. Modern Language Journal, 70(2), 125-132.

[15] MacIntyre, P. D., and R. C. Gardner, 1989. Anxiety and Second Language Learning: Toward a Theoretical Clarification. http://publish.uwo.ca/(Accessed on December 10/2010).

[16] Macintyre, P. D. and R. C. Gardner, 1991a. 'Methods and Results in the Study of Anxiety and Language Learning: A Review of Literature'. Language Learning, 41, 85-117.

[17] Macintyre, P. D. and R. C. Gardner, 1991b. Investigating Language Class Anxiety Using the Focused Essay Technique. The Modern Language Journal. 75. 296-304.

[18] MacIntyre, P. D., and R. C. Gardner, 1994. 'The Subtle effects of Language Anxiety on Cognitive Processing in the Second Language'. Language Learning, 44 (2): 285-305.

[19] Ohata, K., 2005. 'Language Anxiety from the Teacher's Perspective: Interviews with Seven Experienced ESL/EFL Teachers', Journal of Language and Learning, Vol. 3 (1), pp. 133-155 http://jounals.cambridge.org/download.phpfile? (Accessed 14/5/2008).

[20] Onwuegbuzie, A., Bailey, P., \& Daley, C. (2000). Cognitive, Affective, Personality, and Demographic Predictors of Foreign-Language Achievement. The Journal of Educational Research, 94(1), 3-15. Retrieved from http://www.jstor.org/stable/27542298

[21] Onwuegbuzie, A. J. and N. L. Leech, 2004. Enhancing the Interpretation of Significant Findings: The Role of Mixed Methods Research. Paper Presented at the Annual Meeting on the Eastern Educational Research Associations, (February).

[22] Price, M. L. (1991). The subjective experience of foreign language anxiety: Interviews with highly anxious students. In Elaine H. and Dolly Y. (eds.). Language Anxiety: From theory and research to classroom implications. Englewood Cliffs, NJ: Prentice Hall.

[23] Sutarsyah, C. (2017). An Analysis of Student's Speaking Anxiety and its Effect on Speaking Performance. IJELTAL (Indonesian Journal of English Language Teaching and Applied Linguistics), 1(2), 143-152.

[24] Young, D. J., 1991. 'Creating a Low- Anxiety Classroom Environment: What does Language Anxiety Research Suggest?' The Modern Language Journal, 75, 426-435. 